\title{
Danske journaliststuderende: Ret repræsentative reportere
}

AF CHRISTIAN ELMELUND-PRASTEKAER, DAVID NICOLAS HOPMANN OG KLAUS LEVINSEN

Den forskningsbaserede viden om den danske journaliststand er ganske begrænset, men som et skridt på vejen mod større indsigt undersøger denne artikel de danske journaliststuderende. De centrale spørgsmål er, hvem de studerende er, hvorvidt der er forskel på studerende fra forskellige uddannelsesinstitutioner, og om de studerende adskiller sig fra den øvrige befolkning. Selv om de studerende i Roskilde på flere områder adskiller sig fra andre journaliststuderende, er den samlede konklusion, at de kommende journalister er ret repræsentative i forhold til andre danskere på deres egen alder og med samme baggrund. Analyserne bygger på den hidtil mest omfattende spørgeskemaundersøgelse af samtlige danske journaliststuderende.

\section{Introduktion ${ }^{1}$}

Journalistprofessionen er gennem tiden blevet tildelt en vigtig rolle, og anses som tæt koblet til udviklingen af de vestlige liberale demokratier. Fra de tidligste studier af massemediernes samfundsmæssige funktioner har journalisten været set som en ledvogter i den demokratiske samtale (f.eks. White, 1950): Det er journalisterne og mediernes redaktører, der bestemmer, hvad der skal stå i avisen, på nettet, vises på TV og sendes i radioen. Medierne og de enkelte journalister har derved en dagsorden- 
sættende rolle, som i større eller mindre omfang kan være med til at præge den politiske debat (f.eks. Iyengar \& Kinder, 1987; McCombs \& Shaw, 1972). Journalister er således interessante studieobjekter.

Den enkelte journalists karakteristika er imidlertid blot ét element i et samlet mediesystem, som i sig selv kan præge vedkommendes arbejde. Journalister overtager og reproducerer i et vist omfang de institutionsspecifikke normer, som de er en del af. De er - som enhver anden faggruppe - underlagt en række uddannelses-, arbejds- og produktionsvilkår, som de er nødt til at indrette sig efter. Den enkelte journalist eller redaktør har med andre ord ikke frie hænder til at bedrive journalistik eller udfylde ledvogterrollen efter forgodtbefindende (Schudson, 2003; Tunstall, 1971). Den første journalistiske institution, den kommende journalist møder, er uddannelsesinstitutionen. Et naturligt første skridt i opbygningen af forskningsbaseret viden om danske journalister er derfor at kortlægge de danske journaliststuderende.

Et centralt spørgsmål i denne forbindelse er, om de kommende journalister adskiller sig fra den øvrige befolkning med hensyn til deres sociale baggrund, deres grundlæggede samfundsmæssige engagement og politiske holdninger. Er journaliststuderende overklassebørn? Er de mere eller mindre engagerede i samfundet gennem foreninger og organisationer end andre? Er de mere venstreorienterede eller højreorienterede end andre unge danskere? Spørgsmålene er mange, men faktisk er vores viden om de danske journaliststuderende og journalister ikke særlig omfattende. Foruden sammenlignende analyser af flere lande har der været gennemført undersøgelser af både engelske, tyske, norske, svenske, australske og amerikanske journalister eller journaliststuderende (Asp, 2007; Ball et al., 2006; Bjørnsen et al., 2007a; Donsbach, 1990; Fröhlich \& Holtz-Bacha, 2003; Hanna \& Sanders, 2007; Henningham, 1996; Patterson \& Donsbach, 1996; Schultz, 2002, The American Journalist Survey 1971, 1982, 1992, 2002). Videnskabelige undersøgelser af danske journaliststuderende begrænser sig derimod til et mindre studie af journaliststuderende i de fire nordiske lande (Bjørnsen et al., 2007b) med blot 72 danske respondenter. Konkret søger nærværende artikel derfor svar på tre overordnede forskningsspørgsmål: 
1. Hvilken social og uddannelsesmæssig baggrund har de danske journaliststuderende?

2. Adskiller danske journaliststuderende sig fra befolkningen generelt og andre unge specifikt med hensyn til deres samfundsmæssige engagement og deres politiske orientering?

3. Adskiller de tre danske journalistuddannelser sig fra hinanden på de to forrige punkter?

Analysens første undersøgelsesspørgsmål er parallelt med de nævnte internationale studier, hvorfor det i et vist omfang er muligt at sammenligne de danske journaliststuderende med deres medstuderende i andre lande. Problemet i flere af de eksisterende studier er imidlertid, at journaliststuderende hovedsagelig er blevet undersøgt som en isoleret gruppe. På dette punkt adskiller vores undersøgelse sig fra dens internationale sidestykker, idet sigtet - som det fremgår af vort andet spørgsmål - er at sammenligne de journaliststuderende med andre danskere samt unge med en lignende uddannelsesmæssig baggrund.

Endelig er vi med det tredje spørgsmål interesserede i at belyse, om der er forskel mellem de studerende på de tre forskellige uddannelsesinstitutioner. Siden sin oprettelse i 1962 har uddannelsen af danske journalister været knyttet til én uddannelsesinstitution, Danmarks Journalisthøjskole (DJH). Men med introduktionen af de nye journalistuddannelser på henholdsvis Roskilde Universitetscenter (RUC) og Syddansk Universitet (SDU) i 1998 er der sket et brud på dette institutionsmonopol, som gør det interessant at se nærmere på, om de sidstnævnte institutioner tiltrækker (og udvælger) andre typer af studerende. Forskelligheden i de tre journalistuddannelsernes geografiske beliggenhed, institutionelle historie, branchetilknytning og optagelseskriterier må forventes at skabe en øget diversitet i henhold til den sociale sammensætning af de studerende. 


\section{Design og data}

Undersøgelsens empiriske grundlag er spørgeskemadata indhentet fra journaliststuderende på de tre danske journalistuddannelsesinstitutioner i sensommeren 2007. I undersøgelsen indgår alle studerende (inklusive cand.public.-studerende), dog har det ikke været muligt at medtage de SDU- og RUC-studerende, som var i praktik på undersøgelsestidspunktet. Populationen er således studerende på 1.-8. semester på DJH, 1.-4. og 7. semester på SDU samt studerende på 1.-3. modul på RUC. Spørgeskemaet er i alt udsendt til 969 studerende i Århus, 288 i Odense og 119 i Roskilde. Distribution, besvarelse og indsamling af spørgeskemaer er sket i tilknytning til planlagte undervisningsaktiviteter på de respektive uddannelsessteder og på undervisernes opfordring til deltagelse. I alt udfyldte 860 studerende skemaet, hvilket giver en samlet svarprocent på knapt $63(65,55$ og 58 for de tre institutioner). Det reelle frafald er dog mindre, da man må påregne et vist frafald på studierne. Svarprocenten på mindst 63 er tilfredsstillede og markant højere end lignende studier (se f.eks. Bjørnsen et al., 2007b). (For en detaljeret beskrivelse af undersøgelsens metodologi og de stillede spørgsmål se Elmelund-Præstekær et al., 2008).

I vore sammenligninger med andre grupper af danskere trækker vi primært på to datasæt, henholdsvis Valgundersøgelsen 2005 og Værdiundersøgelsen 1999. Begge undersøgelser bygger på repræsentative udsnit af den danske befolkning, og de er de mest aktuelle studier, hvor sammenligning er mulig. Værdiundersøgelsen er desværre ikke af nyere dato, hvorfor sammenligningerne skal tolkes varsomt. Eksempelvis kan danskerne generelt have ændret deres engagement i forskellige klubber og foreninger siden 1999, hvilket alt andet lige vil skævvride sammenligninger med journaliststuderede otte år senere. Vi anvender derfor den mere aktuelle valgundersøgelse mest muligt og antager, at danskernes værdier ikke har ændret sig markant i perioden 1999-2007 på de punkter, hvor vi gennemfører sammenligninger. 


\section{Danskere fra middelklassen - uden stor erfaring}

Når vi interesserer os for spørgsmålet om de journaliststuderendes baggrund, kan det både ses i lyset af den generelle sociologiske debat om middelklassens sociale reproduktion (f.eks. Bourdieu \& Passeron, 1977) men også mere specifikt ud fra forestillingen om, at en professions sociale sammensætning har betydning for, hvilke idealer og ideologier den udvikler og præges af. Hvis man derudover tager for pålydende, at nogle af de studerende kommer til at arbejde nær den politiske, økonomiske og kulturelle magt, og som sådan bliver indlemmet i samfundets elite, så har spørgsmål om, hvilke samfundslag de studerende kommer fra, en bred samfundsmæssig relevans. Dette antydes allerede af blandt andre Johnstone et al. (1976), som pointerer, at medarbejdere i mediebranchen som regel kommer fra de samme sociale lag som dem, der kontrollerer de økonomiske og politiske systemer.

Selv om det naturligvis er vanskeligt at sige noget entydigt om, hvordan en journalists baggrund påvirker vedkommendes faglighed (jf. Shoemaker \& Reese, 1996), er det en rimelig forventning, at en bred rekruttering bidrager positivt til udvikling af mangfoldighed i den journalistiske profession. Af lignende grunde kan man hos uddannelsesinstitutionerne finde et ønske om sikre en vis afspejling af befolkningen i gruppen af studerende (f.eks. Bjørnsen, 2003).

Ses der på de danske journaliststuderende anno 2007, lever de i nogen grad op til ønsket om diversitet. De er i hvert fald delt i to næsten lige store grupper af kvinder og mænd, med en lille overvægt af mænd. På RUC er der imidlertid en overvægt af kvindelige studerende. Når en tidligere undersøgelse fandt en klar overvægt af kvinder (Bjørnsen et al., 2007b: 8), kan det skyldes denne undersøgelses svage empiriske grundlag (i alt 72 studerende). De studerende er også ganske repræsentative, når man ser på, hvor de er vokset op. Svarene fordeler sig helt jævnt på de fem svarmuligheder, vi har givet: Storkøbenhavn, byer med 50.0oo500.000 indbyggere, byer med 10.000-50.000 indbyggere, byer med færre end 10.000 indbyggere samt landdistrikter. En lignende fordeling mellem land og by ses i Norge, hvor fordelingen 
mellem mænd og kvinder dog ikke er så ligelig som i Danmark (Bjørnsen et al., 2007a: 387).

På journalistuddannelserne er der få udenlandske studerende. Mere end 98 procent af respondenterne angiver at være vokset op i Danmark. De få med udenlandsk baggrund kommer enten fra nabolande eller andre vestlige lande. Tidligere studier har nået lignende konklusioner, selv om deltagerne blev spurgt, hvorvidt deres forceldre er vokset op i udlandet. Hér er andelen af studerende med anden baggrund end dansk også ganske lille og mindre end den tilsvarende andel i Sverige, hvor uddannelserne i både Gøteborg og Sundsvall har op mod 8-10 procent studerende med ikke-svenske forældre (Bjørnsen, 2003: 24).

Adskillige studier af social mobilitet viser, at der selv i en omfattende velfærdsstat som den danske er en forholdsvis stærk sammenhæng mellem forældres sociale gruppe og den socialgruppe, som deres børn havner i (Hansen, 1995; McIntosh \& Munk, 2007; Munk, 2003). Det er således et velkendt fænomen, at der findes en overrepræsentation af unge fra middelklassen på de videregående uddannelser. Journalistuddannelserne er ingen undtagelse. Det gennesnitlige uddannelsesniveau hos de journaliststuderendes forældre er således betydeligt højere end uddannelsesniveauet for resten af befolkningen i samme aldersgruppe (de 43-58-årige, Valgundersøgelsen 2005). Samme billede ses i resten af Norden (Bjørnsen et al., 2007b: 6-8).

Inden for visse professioner, eksempelvis lægeprofessionen, taler man ikke blot om en overrepræsentation af studerende med veluddannede forældre men om eksistensen af et „lukket kredsløb“. Op mod en fjerdedel af de lægestuderende har nemlig forældre, der selv er læger (Aagaard, 2006). Selvom journalistuddannelserne på samme måde uddanner studerende til et særligt erhverv, er kredsløbet i mindre grad lukket. Dog må man sige, at det journalistiske „gen“ går i arv, idet knapt 15 procent af de adspurgte er i nær familie med journalister. Igen adskiller Danmark sig ikke fra de andre nordiske lande, dog har en langt mindre andel af de svenske journaliststuderende journalistforældre (Bjørnsen et al., 2007b: 8).

Ser man på de studerendes egen uddannelsesmæssige baggrund, er det iøjnefaldende, at en meget stor del højest har en 


\section{Tabel 1}

Journaliststuderendes tidligere (højeste) uddannelse, fortelt på uddannelsessted (procent)

\begin{tabular}{lrrr}
\hline & SDU & DJH & RUC \\
\hline Gymnasial uddannelse & 77 & 82 & 19 \\
\hline Faglig erhvervsuddannelse & 3 & 5 & 0 \\
\hline Kort videregående uddannelse & 6 & 4 & 5 \\
\hline Professionsbachelor & 2 & 1 & 6 \\
\hline Universitetsbachelor & 11 & 8 & 70 \\
\hline Kandidatuddannelse & 1 & 0 & 0 \\
\hline I alt & 100 & 100 & 100 \\
\hline $\mathrm{N}$ & 138 & 547 & 64 \\
\hline
\end{tabular}

Note: Andelene for SDU og DJH er beregnet for de studerende på bacheloruddannelsen alene. RUC-andelene er beregnet for alle studerende.

gymnasial uddannelse (tabel 1). Det gælder både i Odense og i Århus, men naturligvis ikke i Roskilde, hvor optagelse kræver en bachelorgrad. Det kan derfor undre, at 19 procent af de RUC-studerende alligevel angiver, at de højest har en gymnasial uddannelse bag sig. Det kan muligvis skyldes, at nogle RUC-studerende opfatter deres basisuddannelse som en del af deres journalistiske (overbygnings-)udannelse. På både DJH og SDU uddannes kandidater i journalistik (cand.public.), og disse studerende har nødvendigvis også en bachelorgrad bag sig. Hvis vi ekskluderer cand.public.'erne fra analysen, viser det sig, at omkring 80 procent at de studerende højest har en gymnasial uddannelse (lidt flere i Århus end i Odense). ${ }^{2}$

En mindre gruppe af studerende på SDU og DJH har en universitetsbachelor. Disse studerende har altså valgt at tage en traditionel journalistuddannelse og ikke kandidatuddannelsen i journalistik efter deres afsluttede bachelorgrad. Det er interessant, fordi uddannelsesinstitutionerne netop har oprettet cand.public.-uddannelserne for at tiltrække journalistikinteresserede med universitetsbaggrund. Kandidatuddannelserne er dog fortsat ret nye (særligt på DJH), og ikke alle bachelorstudier giver direkte eller i det mindste „smidig“ adgang til kandidatuddan- 
nelserne i journalistik, hvilket kan være en årsag til, at så relativt mange journaliststuderende har en universitetsbachelor.

Endelig må vi aflive den udbredte forestilling om, at flertallet af journaliststuderende ligger i journalistisk træningslejr på en højskole inden studiestart. Når man spørger til de studerendes journalistiske erfaring forud for studiestart, svarer blot omkring en fjerdedel, at de har modtaget journalistisk undervisning (f.eks. på en højskole), inden de begyndte på journalistuddannelsen. Faktisk er det en smule mere almindeligt, at man som nystartet journaliststuderende har erfaring med journalistik på anden vis, eksempelvis gennem praktik eller lønnet arbejde. Det skal dog nævnes, at fordelingen mellem de forskellige typer af journalistisk erfaring skal tolkes varsomt, da respondenterne kun havde mulighed for at vælge én kategori. Studerende, der har flere typer af erfaring, formodes at have sat kryds ved den kategori, hvorfra deres erfaring primært stammer. Der kan dog også forekomme en såkaldt rækkefølgeeffekt, som medfører for mange svar i kategorien „Journalistisk uddannelse“. Tilbage står dog, at næsten halvdelen af de studerende ikke havde nogen form for journalistisk erfaring forud for studiestart, hvilket er en meget stor andel i sammenligning med både Norge og Finland. På dette punkt ligner de danske studerende mere de svenske, som heller ikke i stort omfang har arbejdet med journalistik før studiet (Bjørnsen et al., 2007b: 8).

Der er visse forskelle mellem de tre danske uddannelsesinstitutioner. En markant større andel - knap en tredjedel - af de studerende på SDU end på DJH og RUC har modtaget undervisning i journalistik forud for studiestart. Og på både SDU og RUC har en større andel end på DJH angivet at have ,,anden“ journalistisk erfaring. Således er det kun godt en tredjedel af de studerende på de to nye uddannelser, der var journalistisk jomfruelige ved studiestart. Når de SDU-studerende med deres gennemsnitlige alder på 24,5 år samtidig er de yngste (ét år yngre end DJH-studerende og godt to år yngre end RUC-studerende), må man konkludere, at SDU-studerende på kortere tid har høstet mere erfaring inden for journalistikken end andre. En mulig årsag kan være, at uddannelsen i Odense gennem dens optagelsesprøver (som inkluderer individuelle samtaler med ansøgerne) i højere grad end an- 
dre screener ansøgerne for netop førstehåndskendskab til den journalistiske profession.

Samlet set understreger de nutidige studerendes relativt lave alder, deres ensartede uddannelsesbaggrund og deres relativt begrænsede journalistiske erfaring, at journalistuddannelsen er blevet en uddannelse på linje med andre uddannelser. Tidligere var det almindeligt at være faglært, eksempelvis landmand, inden man gik i (mester-)lære som journalist (Øgendahl, 1995: 9). Til sammenligning har under en tiendedel af de nystartede studerende en erhvervsmæssig eller kort videregående uddannelse i dag.

\section{Stort samfundsmæssigt engagement}

Idealet om den objektive og neutrale journalist kan indebære et normativt ønske om, at journalister og journaliststuderende ikke personligt har aktier i bestemte politiske interesser. Således synes der inden for den politiske journalistik i Danmark at herske en norm om, at journalister ikke bør være partimedlemmer (Bertelsen, 2003). Da det kom frem i april 2008, at forhenværende minister Lotte Bundsgaard som nystartet journaliststuderende på SDU havde opgivet sit medlemskab af Socialdemokraterne, var uddannelseslederen, Troels Mylenberg, tilfreds: „Hun viser, at hun vil være journalist med hud og hår, og at hun tager sin nye profession så alvorligt, at hun vil gøre meget for at undgå potentielle interessekonflikter" (Fyens Stiftstidende, d. 9. april 2008). En sådan norm kan selvsagt diskuteres, men hvis den er stærk og indlæres allerede på journalistuddannelsen, må man forvente en lavere partimedlemsfrekvens blandt journaliststuderende end blandt andre unge. Et interessant spørgsmål er dernæst, hvorvidt en sådan neutralitetsnorm slår igennem på andre områder end det politiske og får de studerende til at melde sig ud af upolitiske foreninger og klubber. Vores undersøgelse af de studerendes samfundsmæssige engagement viser, at de er mindst lige så engagerede som befolkningen i almindelighed og som andre unge med lignende baggrund (tabel 2). Da langt de fleste journaliststuderende som beskrevet har en gymnasial uddannelse og er mellem 24 og 26 år i gennemsnit, vurderer vi, at gruppen af under 30- 


\section{Tabel 2}

Samfundsmæssigt engagement målt som andele af respondenter, der tilhører eller er medlem af forskellige grupper; journaliststuderende, unge og alle danskere (procent)

\begin{tabular}{|c|c|c|c|c|c|c|}
\hline & DJH & SDU & RUC & $\begin{array}{c}\text { Alle } \\
\text { jour. stud. }\end{array}$ & Unge & $\begin{array}{c}\text { Alle } \\
\text { danskere }\end{array}$ \\
\hline $\begin{array}{l}\text { Socialt } \\
\text { arbejde for } \\
\text { ældre, han- } \\
\text { dicappede } \\
\text { og fattige* }\end{array}$ & 6 & 8 & 10 & 7 & 2 & 8 \\
\hline $\begin{array}{l}\text { Uddannelse, } \\
\text { kunst, musik, } \\
\text { og kulturelle } \\
\text { aktiviteter* }\end{array}$ & 42 & 48 & 52 & 44 & 25 & 20 \\
\hline Fagforeninger & 76 & 75 & 73 & 76 & 51 & 64 \\
\hline $\begin{array}{l}\text { Politisk parti } \\
\text { eller politisk } \\
\text { gruppe }\end{array}$ & 8 & 12 & 12 & 9 & 6 & 8 \\
\hline $\begin{array}{l}\text { Udviklingen } \\
\text { i den } 3 \text {. verden/ } \\
\text { menneske- } \\
\text { rettigheder* }\end{array}$ & 31 & 24 & 35 & 30 & 14 & 5 \\
\hline $\begin{array}{l}\text { Naturbeskyt- } \\
\text { telse, miljø, } \\
\text { økologi og } \\
\text { dyrebeskyttelse* }\end{array}$ & 10 & 9 & 22 & 11 & 14 & 16 \\
\hline Ungdomsarbejde & 6 & 8 & 12 & 7 & 9 & 8 \\
\hline $\begin{array}{l}\text { Sport, fritids- } \\
\text { aktiviteter }\end{array}$ & 50 & 49 & 65 & 52 & 46 & 39 \\
\hline Kvindegrupper & 2 & 3 & 9 & 3 & 0 & 3 \\
\hline $\begin{array}{l}\text { Freds- } \\
\text { bevægelser }\end{array}$ & 3 & 3 & 4 & 3 & 2 & 1 \\
\hline Andre & 15 & 15 & 15 & 15 & 15 & 17 \\
\hline Gennemsnit & 23 & 23 & 28 & 23 & - & - \\
\hline
\end{tabular}

Note: DJH: N=554; SDU: N=158; RUC: N=69. „Unge“ er personer under 30 år, der har en gymnasie- eller hf-eksamen. Både „unge“ og „alle danskere“ er hentet fra Værdiundersøgelsen 1999 (v68, v70, v72, v74, v76, v80, v82, v86, v88, v90, v92, v96), N=65 og 866.

* Formuleringen i Værdiundersøgelsen er lidt mere snæver, henholdsvis: „Socialt arbejde“, „Uddannelse, kunst el. lign.“, „Dyrebeskyttelsesforeninger el. lign.“ og „Menneskerettighedsforening el. lign.“. Grundet disse forskelle er der ikke beregnet et gennemsnit for grupperne „unge“ og „alle“. 
årige med en gymnasie- eller hf-eksamen er den mest sammenlignelige, vi kan identificere i de undersøgelser, som journaliststuderende kan sammenlignes med.

De studerendes markante engagement i foreninger for uddannelse, kultur, musik og kulturelle aktiviteter samt i foreninger for udvikling i den tredje verden og menneskerettigheder må ikke overfortolkes, da måleforskelle mellem de to undersøgelser gør sammenligning vanskelig. Af særlig interesse er dog, at de studerende er markant oftere fagforeningsmedlemmer og på SDU og RUC også oftere medlemmer af politiske foreninger, end både den danske befolkning som helhed og andre unge er. Konklusionen er derfor, at de journaliststuderende ikke følger normen om at undlade at engagere sig i partipolitik. Og eftersom de studerende på en række områder er mere engagerede i samfundet end både den "almindelige“ dansker og andre unge, er der heller intet tegn på, at denne norm slår igennem på andre områder. Danske journaliststuderendes relativt store foreningsengagement og „sociale kapital“ kan tolkes som udtryk for, at de finder inspiration til deres studier og professionelle virke i en mangfoldighed af aktiviteter uden for studiet.

Samme billede gør sig gældende, hvis man ser på samfundsmæssig deltagelse af mere uformel karakter (tabel 3). Også her ligger deltagelsesniveauet hos samtlige journaliststuderende en smule over gruppen af andre unge og markant over deltagelsen blandt befolkningen som helhed. De journaliststuderende deltager eller overvejer at deltage i omtrent samme antal underskriftsindsamlinger som andre unge, men deltager lidt mere i boykots, lovlige demonstrationer, overenskomststridige strejker og besættelser.

Der er kun marginale forskelle mellem de studerende fra de forskellige uddannelser. Specielt DJH- og SDU-studerende har et næsten ens medlemsmønster, mens RUC-studerende er lidt mere engagerede. Samlet set er konklusionen, at de journaliststuderende er mere engagerende i både samfundet bredt set og $\mathrm{i}$ politik snævert set, end danskerne i almindelighed er. Endvidere er de studerende på samme måde lidt mere engagerede end andre unge med samme baggrund, også selv om denne gruppe er ligeså politisk interesseret som danske journaliststuderende. 


\section{Tabel 3}

Uformelle deltagelsesformer målt som andele af respondenter, der har eller muligvis vil deltage i forskellige aktiviteter; journaliststuderende, unge samt alle danskere (procent)

\begin{tabular}{lcccccc}
\hline & DJH & SDU & RUC & $\begin{array}{c}\text { Alle } \\
\text { jour. stud. }\end{array}$ & Unge & $\begin{array}{c}\text { Alle } \\
\text { danskere }\end{array}$ \\
\hline $\begin{array}{l}\text { Underskrifts- } \\
\text { indsamlinger }\end{array}$ & 96 & 92 & 93 & 95 & 94 & 84 \\
\hline Boykot & 84 & 92 & 95 & 87 & 82 & 62 \\
\hline $\begin{array}{l}\text { Lovlige } \\
\text { demonstrationer }\end{array}$ & 89 & 91 & 94 & 90 & 86 & 69 \\
\hline $\begin{array}{l}\text { Overenskomst- } \\
\text { stridige strejker }\end{array}$ & 87 & 91 & 92 & 88 & 71 & 53 \\
\hline $\begin{array}{l}\text { Besættelser af } \\
\text { bygninger eller } \\
\text { fabrikker }\end{array}$ & 21 & 25 & 26 & 23 & 20 & 20 \\
\hline $\begin{array}{l}\text { Foretage et } \\
\text { politisk } \\
\text { forbrugsvalg }\end{array}$ & 91 & 91 & 100 & 92 & - & - \\
\hline $\begin{array}{l}\text { Gennemsnit } \\
\text { (eks. politisk } \\
\text { forbrug) }\end{array}$ & 75 & 78 & 80 & 77 & 71 & 58 \\
\hline
\end{tabular}

Note: Vist er andel af respondenter, der har "har" eller "muligvis vil“ deltage. Kun respondenter, der angiver placering, er medtaget. Ikke lige mange svarer på hvert inkluderet spørgsmål, hvorfor de angivne $\mathrm{N}$ er maksimale, $\mathrm{DJH}$ : $\mathrm{N}=557$; SDU: $\mathrm{N}=158$; RUC: $\mathrm{N}=68$. „Unge" er personer under 30 år, der har en gymnasie- eller hf-eksamen. Både „unge“ og „alle danskere” er hentet fra Værdiundersøgelsen 1999 (v235-v239), N=79 og 995.

\section{De røde unge - og repræsentative journaliststuderende}

Det giver jævnligt anledning til diskussion i medierne, at journalister og journaliststuderende angiveligt skulle være venstreorienterede. Senest skete det i forbindelse med en „analyse“ af valgdækningen i 2007 på DR og TV2 gennemført af Ralf Pittelkow i Jyllands-Posten d. 2. december 2007. Disse diskussioner er dog som regel behæftet med en række problemer: Da der ikke findes repræsentative studier af danske journalister, bygger konklusionerne enten på undersøgelser med få respondenter (Bjørnsen et 
al., 2007b) eller studiestedernes egne, uvidenskabelige unders $\emptyset$ gelser gennemført ved eksempelvis studiestart.

Skulle de journaliststuderende have bestemt Folketingets sammensætning ved valget i efteråret 2007, ville det have set markant anderledes ud (tabel 4). Der ville være langt færre socialdemokrater, venstrefolk og DF'ere. I stedet ville der have været markant flere radikale og SF'ere. Hvis partiernes styrke summeres inden for de to blokke, der ved valget i 2007 støttede hen-

\section{Tabel 4}

Partivalg, fordelt på journaliststuderende, unge samt alle danskere (procent)

\begin{tabular}{lcccccc}
\hline & DJH & SDU & RUC & $\begin{array}{c}\text { Alle } \\
\text { jour. stud. }\end{array}$ & Unge & $\begin{array}{c}\text { Alle } \\
\text { danskere }\end{array}$ \\
\hline $\begin{array}{l}\text { A. Social- } \\
\text { demokraterne }\end{array}$ & 19 & 17 & 16 & 18 & 18 & 26 \\
\hline $\begin{array}{l}\text { B. Det Radikale } \\
\text { Venstre }\end{array}$ & 21 & 24 & 25 & 22 & 6 & 5 \\
\hline $\begin{array}{l}\text { C. Det Konservative } \\
\text { Folkeparti }\end{array}$ & 8 & 9 & 3 & 8 & 4 & 8 \\
\hline $\begin{array}{l}\text { F. Socialistisk } \\
\text { Folkeparti }\end{array}$ & 27 & 23 & 35 & 27 & 32 & 15 \\
\hline $\begin{array}{l}\text { K. Kristen- } \\
\text { demokraterne }\end{array}$ & 1 & 0 & 0 & 0 & 2 & 1 \\
\hline $\begin{array}{l}\text { O. Dansk } \\
\text { Folkeparti }\end{array}$ & 2 & 3 & 0 & 2 & 4 & 9 \\
\hline $\begin{array}{l}\text { V. Venstre } \\
\text { Y. Ny Alliance }\end{array}$ & 11 & 11 & 6 & 11 & 23 & 30 \\
\hline $\begin{array}{l}\text { D. Enhedslisten } \\
\text { Balance }\end{array}$ & 5 & 5 & 5 & 7 & 6 & 4 \\
\hline $\begin{array}{l}\text { (fordel til } \\
\text { borgerlige) }\end{array}$ & -45 & -37 & -72 & -44 & -26 & 2 \\
\hline N & 505 & 149 & 63 & 717 & 114 & 3.492 \\
\hline
\end{tabular}

Note: Kun respondenter, der har angivet et partivalg, er medtaget. „Unge“ og „alle danskere" bygger på undersøgelser foretaget af Capacent Epinion for Syddansk Universitet gennem valgkampen 2007. „Unge“ er personer under 30 år, der har en gymnasie- eller hf-eksamen. 
holdsvis en borgerlig ( $\mathrm{V}, \mathrm{K}, \mathrm{O}$ og $\mathrm{Y}$ ) og en socialdemokratisk (A, B, F, K og Ø) regering, og trækkes blokkenes styrke fra hinanden, får man et indtryk af det samlede styrkeforhold mellem de to mulige regeringskoalitioner. Som det fremgår af tabel 4, var der en lille overvægt til de borgerlige i den samlede befolkning, mens der blandt de journaliststuderende - særligt på RUC - var en klar overvægt til det socialdemokratiske alternativ. Det var der i imidlertid også blandt unge på under 30 år med en gymnasie- eller hfeksamen.

Forskellen mellem journaliststuderende (i hvert fald dem i Århus og i Odense) og gruppen af andre unge vist i tabel 4 skyldes ikke, at de journaliststuderende er relativt mere venstreorienterede. Sammenlignes de to grupper af unge vælgere, er det kun De Radikale, der er markant overrepræsenteret hos de journaliststuderende. Samtidig opvejes underrepræsentationen af Venstre og Dansk Folkeparti i nogen grad af, at en del studerende er villige til at stemme på De Konservative og Ny Alliance. Det er samtidigt værd at bemærke, at den store gruppe af journaliststuderende ikke stemmer mere på venstrefløjspartierne, Socialistisk Folkeparti og Enhedslisten, end andre unge.

Samlet set indikerer disse resultater, at kun RUC-studerende er mere røde end andre unge med en lignede baggrund, mens de journaliststuderede på DJH og SDU „blot“ ønsker et regeringsskifte og større indflydelse til midten i dansk politik.

Spørgsmålet om politisk orientering kan undersøges på en anden, mere abstrakt facon. Valgundersøgelserne har gennem mange år bedt respondenterne om at placere sig selv på en venstre-højreskala, hvor o er mest venstreorienteret og 10 mest højreorienteret. Beskriver man sig selv med et femtal, er man altså hverken venstre- eller højreorienteret, mens værdier på mindre end fem indikerer orientering mod venstre og værdier større end fem orientering mod højre. Tabel 5 viser de gennemsnitlige venstre-højreplaceringer for de forskellige journaliststuderende sammenholdt med deltagerne i valgundersøgelsen 2005. Resultatet harmonerer med konklusionen ovenfor: Hvor de journaliststuderende set under ét er mere venstreorienterede end den samlede befolkning, er det kun de studerende på RUC, der er mere venstreorienterede end gruppen af unge under 30 år med 


\section{Tabel 5}

Gennemsnitlig placering på venstre-højreskalaen (0-10); journaliststuderende, unge samt alle danskere (procent)

\begin{tabular}{lcc}
\hline & Gennemsnit (0-10) & N \\
\hline DJH & 5,01 & 540 \\
\hline SDU & 4,70 & 149 \\
\hline RUC & 3,60 & 67 \\
\hline Alle journaliststuderende & 4,82 & 756 \\
\hline Unge & 4,41 & 157 \\
\hline Alle danskere & 5,13 & 2.553 \\
\hline
\end{tabular}

Note: Kun respondenter, der angiver placering, er medtaget. „Unge“ er personer under 30 år, der har en gymnasie- eller hf-eksamen. Både „unge“ og „alle danskere“ er hentet fra Valgundersøgelsen 2007 (hv_selvplac).

en gymnasie- eller hf-uddannelse. Både DJH- og SDU-studerende har omtrent samme ideologiske placering som gruppen af andre unge. Faktisk er de studerende hér en anelse mindre venstreorienterede end deres tidligere medstuderende i gymnasiet.

Dansk politik består imidlertid ikke kun af én dimension, hvorpå vælgere kan være enige eller uenige (Borre, 2003; Larsen \& Lolle, 2007). For at få en dybere forståelse af de studerendes holdninger er det nødvendigt at skelne mellem forskellige typer af politik. I den forbindelse har vi genbrugt et spørgsmålsbatteri fra Valgundersøgelsen 2005, der beder deltagerne angive, om de mener, at det offentlige bruger for mange, for få eller en passende mængde penge på en række områder (forsvar, sundhed, uddannelse, folkepension, miljø, kultur, børnehaver og vuggestuer, arbejdsløshedsunderstøttelse til den enkelte, bistandshjælp, ulandsbistand, flygtninge/indvandrere, hjemmehjælp, kollektiv trafik, børnefamilier og forskning). På den baggrund har vi konstrueret to indeks bestående af henholdsvis seks og fire udvalgte udgiftsspørgsmål og beregnet et samlet udtryk for holdningerne til dels fordelingspolitiske spørgsmål (udgifter til sundhed, folkepension, hjemmehjælp, børnepasning, arbejdsløshedsunderstøttelse og bistandshjælp), dels værdipolitiske spørgsmål (udgifter til miljø, ulande, kultur og flygtninge/indvandrere). 


\section{Figur 1}

Journaliststuderendes, unges samt alle danskeres score på et værdi- og fordelingspolitisk indeks

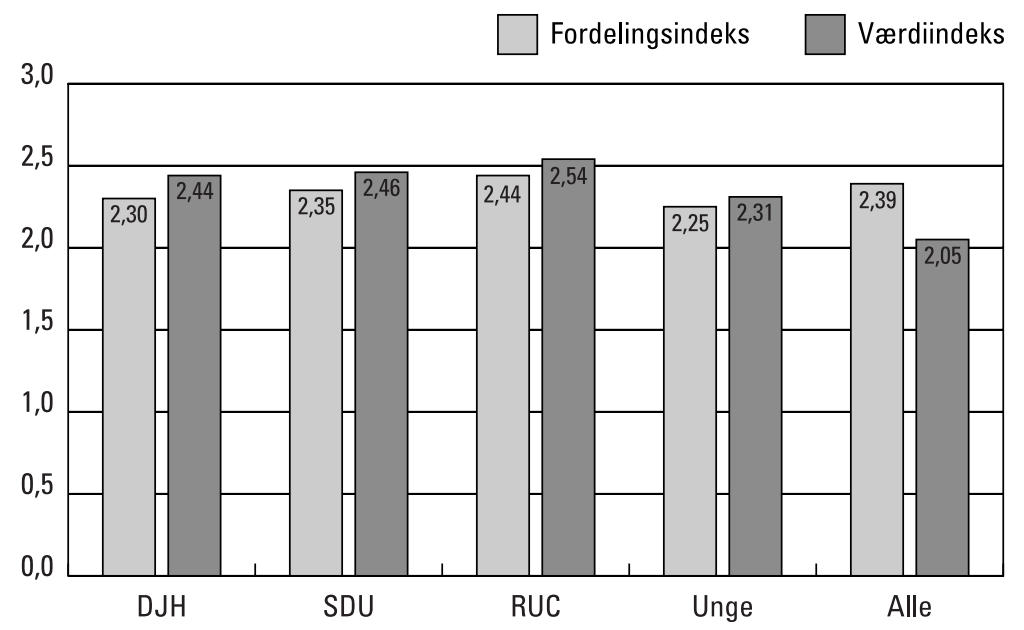

Note: De oprindelige svarmuligheder "for meget", "passende" og "for lidt" tildeles værdierne "1", ,2", og „3“. Indekset er beregnet ved at lægge de enkelte respondenters score på de inkluderede spørgsmål sammen og derpå dele summen med antallet af inkluderede spørgsmål. Indekset får dermed samme spænd som de oprindelige spørgsmål. En indeksværdi på 1 betyder, at det offentlige bruger for mange penge på alle spørgsmål i indekset. En værdi på 3 betyder, at det offentlige bruger for få penge på alle spørgsmål $\mathrm{i}$ indekset. Kun respondenter, der har angivet holdning til samtlige spørgsmål i de enkelte indeks, er medtaget. Ikke lige mange svarer på det enkelte spørgsmål, hvorfor de angivne $\mathrm{N}$ er maksimale, DJH: $\mathrm{N}=409$; SDU: $\mathrm{N}=111 ; \mathrm{RUC}$ : $\mathrm{N}=49$. „Unge“ er personer under 30 år, der har en gymnasie- eller hf-eksamen. Både „unge“ og „alle“ er hentet fra Valgundersøgelsen 2005 (v250), N=122 og 1733.

Af figur 1 fremgår det, at journaliststuderende generelt er mere venligt stemte over for offentlige udgifter end andre unge med gymnasiebaggrund samt resten af danskerne. Tallene indikerer, at RUC'erne er mest udgiftsvenlige, men forskellene er ikke store. Det mest interessante i figur 1 er derfor, at den afslører, at de studerende alene adskiller sig fra den almene befolkning, når det gælder værdipolitiske spørgsmål. Mens den gennemsnitlige studerende er nogenlunde enig med den gennemsnitlige dansker om, hvor meget (mere) det offentlige skal investere i blandt andet børnehave og hjemmehjælp, så ønsker de studerede at anvende flere ressourcer på blandt andet ulande og indvandrere, end den 
samlede befolkning gør. I denne konklusion kan ligge en del af forklaringen på, hvorfor journaliststuderende opfattes som venstreorienterede, når de går ind for større offentligt forbrug i eksempelvis kultur- eller miljøpolitikken. De studerende har ganske enkelt opprioriteret værdipolitik eller „ny politik“, som denne dimension i moderne politik også har været kaldt. Men en sådan opprioritering er ikke nødvendigvis venstreorienteret: Figur 1 indikerer snarere, at der er tale om en generationseffekt, eftersom andre unge på samme vis har opprioriteret værdipolitikken.

De danske journaliststuderende kan med andre ord højest kaldes „værdipolitisk venstreorienterede“. Men ønsker man at anvende en sådan betegnelse om de kommende journalister, må man samtidig anvende den om andre unge med gymnasiebaggrund. Politisk orientering er altid en relativ størrelse, som kun giver mening gennem sammenligning. Spørgsmålet er, hvilken gruppe det er mest rimeligt at sammenligne journaliststuderende med? I vores diskussion har vi lagt vægt på, at de journaliststuderende netop er studerende, og at man derfor må afvente studier af det samlede danske journalistkorps, før det giver mening at sammenholde journalistholdninger med holdninger blandt danskere i al almindelighed. Samtidig vil vi erindre om, at der fortsat på ingen måde er ført bevis for, at der skulle være en sammenhæng mellem de studerendes (eller journalisternes) personlige politiske værdier og deres professionelle virke.

\section{Konklusion}

En enkeltstående undersøgelse kan naturligvis ikke svare fyldestgørende på, hvem de danske journaliststuderende er. Denne artikel har dog taget det første skridt, og den overordnende konklusion er, at journaliststuderende på mange måder er ganske repræsentative - $\mathrm{i}$ hvert fald i forhold til den gruppe de kommer fra, nemlig unge med gymnasiebaggrund. Det normative ideal om, at journalister skal repræsentere det samfund, de bedriver journalistik i, er således imødekommet på flere områder.

Mere specifikt konkluderer vi, at de studerende i lighed med andre unge på videregående uddannelser kommer fra veluddannede hjem. Disse hjem ligger i lige stort tal i Storkøbenhavn, 
større og mindre provinsbyer, landsbyer og landdistrikter. På denne måde afspejler de kommende journalister, at Danmark består af både byer og landområder, ligesom den ligelige fordeling mellem mænd og kvinder er repræsentativ.

De studerende kommer for de flestes vedkommende direkte fra gymnasiet, og halvdelen har ingen journalistisk erfaring forud for studiestart. Få har været i praktik eller lønnet arbejde, mens omkring en fjerdedel har modtaget undervisning i journalistik eksempelvis på en højskole.

Blandt de journaliststuderende er normen om ikke at engagere sig partipolitisk tilsyneladende svag. Og den påvirker ikke de studerendes øvrige samfundsengagement. Faktisk er de studerende lidt oftere medlemmer af forskellige foreninger og organisationer end både andre unge og befolkningen som helhed. De deltager også lidt hyppigere end andre i uformelt organiserede deltagelsesformer som boykots, strejker og demonstrationer. Denne deltagelse og aktivisme er klart større end den gennemsnitlige befolknings, men den er kun marginalt større end deltagelsen blandt andre unge med en sammenlignelig baggrund, hvorfor man også på dette punkt kan tale om repræsentative journaliststuderende.

De studerede er, stærke forestillinger til trods, ikke markant venstreorienterede. Faktisk indikerer resultaterne, at de journaliststuderende er en anelse mindre venstreorienterede end gruppen af andre unge, hvilket også ses i deres partivalg: Flertallet til de studerendes fiktive socialdemokratiske regering bygger på en meget stor støtte til De Radikale - ikke på uforholdsmæssig stor opbakning til Socialistisk Folkeparti eller Enhedslisten. Igen afspejler de studerende altså den bredere befolkning, og myten om de røde lejesvende må nuanceres.

Endelig eksisterer der visse forskelle mellem de journaliststuderende fra de tre forskellige uddannelsesinstitutioner. De studerende på RUC er ikke blot ældre end dem på DJH og SDU, de er også mere venstreorienterede, mere politisk interesserede og oftere medlemmer af forskellige foreninger og organisationer. Enten tiltrækker RUC-uddannelsen en lidt anden type studerende, eller også præger uddannelsen de studerende, der kommer, på en anderledes måde, end uddannelserne i Odense og Århus gør. 
Forskellene skyldes muligvis, at RUC-uddannelsen formelt adskiller sig fra de to andre ved at være en kandidatuddannelse, der bygger oven på en bachelorgrad i et andet fag. Om sådanne institutionelle forskelle kan forklare variansen, kan ikke afgøres her, men må efterlades til fremtidige longitudinale studier.

Alt i alt viser undersøgelsen, at de studerende ser ud til at kunne blive ret repræsentative reporterer.

\section{N OTER}

1. For kommentarer til tidligere versioner af denne artikel samt samarbejdet om dataindsamlingen takker vi Erik Albæk, Ulrik Kjær, Poul Erik Mouritzen, Troels Mylenberg, Signe Pihl-Thingvad, Charlotte Wien (alle Syddansk Universitet), Solveig Schmidt (Danmarks Journalisthøjskole) og Ida Schultz (Roskilde Universitetscenter) samt studentermedhjælperne Therese Dyrby og Julie Nørrelund og alle de studerende, der tog sig tid til at udfylde vores spørgeskema. Fejl og mangler er selvfølgelig vort ansvar alene.

2. Da undersøgelsen er fortaget på den samlede population, og ikke et tilfældigt udvalg, har vi valgt ikke at foretage signifikanstests af de rapporterede forskelle i procentandele.

\section{REFEREN CER}

Asp, Kent (red.) (2007). Den svenska journalistkåren. Göteborg: Institutionen för journalistik och massekommunikation, Göteborg Universitet.

Ball, Amanda, Mark Hanna \& Karen Sanders (2006). "What British Journalism Students Think about Ethics and Journalism”, Journalism \& Mass Communication Educator, 61. årg., nr. 1, pp. 20-32.

Bertelsen, Anja (2003). „Partibøger udbredt blandt journalister“, Journalisten, nr. 19.

Bjørnsen, Gunn (2003). Projektrapport 2: Journalistik i flere farver. Flerkulturell bakgrunn som journalistisk kompetanse? Om rekruttering og utdanning av „nynordiske“ journalister. Århus: Nordisk Journalistcenter. 
Bjørnsen, Gunn, Jan Fredrik Hovden \& Rune Ottosen (2007a). “Journalists in the Making: Findings from a Longitudinal Study of Norwegian Journalism Students”, Journalism Practice, 1. årg., nr. 3, pp. 383-403.

Bjørnsen, Gunn, Jan Fredrik Hovden, Rune Ottosen, Ida Schultz \& Henrika Zilliacus-Tikkanen (2007b). The Nordic Journalism Student: A Cross-National Study. ICA Conference. San Francisco.

Borre, Ole (2003). „To konfliktdimensioner“, pp. 171-186 i: Jørgen Goul Andersen \& Ole Borre (red.). Politisk forandring. Værdipolitik og nye skillelinier ved folketingsvalget 2001, Århus: Systime.

Bourdieu, Pierre \& Jean Claude Passeron (1977). Reproduction in Education, Society and Culture. London: Sage Publications.

Donsbach, Wolfgang (1990). „Journalistikstudenten im internationalen Vergleich“, Publizistik, 35. årg., pp. 408-427.

Elmelund-Præstekær, Christian, David Nicolas Hopmann \& Klaus Levinsen (2008). „Den danske journalistundersøgelse: Holdninger til journalistik og samfund. Projektbeskrivelse og teknisk rapport for 2007-undersøgelsen“, Politologiske Skrifter, nr. 20.

Fröhlich, Romy \& Christina Holtz-Bacha (red.) (2003). Journalism Education in Europe and North America: An International Comparison. Cresskill: Hampton Press.

Hanna, Mark \& Karen Sanders (2007). "Journalism Education in Britain: Who are the Students and What do they Want?" Journalism Practice, 1. årg., nr. 3, pp. 404-420.

Hansen, Erik Jørgen (1995). „En generation blev voksen. Den første velfærdsgeneration“, Socialforskningsinstituttets Rapport, 95. årg., nr. 8.

Henningham, John (1996). “Australian Journalists' Professional and Ethical Values”, Journalism and Mass Communication Quarterly, 73. årg., nr. 1, pp. 206-2218.

Iyengar, Shanto \& Donald Kinder (1987). News that Matters. Television and American Opinion. Chicago: The University of Chicago Press.

Johnstone, John, Slawski Edward \& William Bowman (1976). The News People: A Sociological Portrait of American Journalists and Their Work. Chicago: University of Illinois Press.

Larsen, Christian Albrekt \& Henrik Lolle (2007). „Vælgernes mentale kort over partierne fra 1994 til 2005: Én venstrehøjre dimension og én protest/ekstremist dimension“, pp. 233-256 i: Jørgen Goul Andersen, Ole Borre, Kasper Møller Hansen \& Hans Jørgen Nielsen (red.). Det nye 
politiske landskab: Folketingsvalget 2005 i perspektiv, Århus: Academica.

McCombs, Maxwell \& Donald Shaw (1972). "The Agenda-Setting Function of Mass Media”, Public Opinion Quarterly, 36. årg., nr. 2, pp. 176187.

McIntosh, James \& Martin Munk (2007). Family background and educational choices: Changes over five Danish cohorts. The 22nd Congress of the European Economic Association. Budapest.

Munk, Martin (2003). „Livschancer og social mobilitet - forskellige fødselsårganges vilkår“, Dansk Sociologi, nr. 4, pp. 41-58.

Patterson, Thomas \&Wolfgang Donsbach (1996). "Journalists as Partisan Actors”, Political Communication, 13. årg., pp. 455-468.

Schudson, Michael (2003). The Sociology of News. New York: W.W. Norton \& Company.

Schultz, Tanjev (2002). “Does Education Matter? Characteristics of Journalists who went to Graduate School”, Journalism \& Mass Communication Educator, 3. årg., nr. 2, pp. 223-238.

Shoemaker, Pamela \& Stephen Reese (1996). Mediating the Message Theories of Influences on Mass Media Content. New York: Longman.

Tunstall, Jeremy (1971). Journalists at Work: Specialist Correspondents, their News Organizations, News Sources and Competitor Colleagues. London: Constable.

White, David Manning (1950). “The Gatekeeper: A Casestudy in the Selection of News”, Journalism Quarterly, 27. årg., nr., pp. 383-39o.

Øgendahl, Claus (1995). Dansk Journalistliv 1920-1970. Odense: Odense Universitetsforlag.

Aagaard, Janne (2006). „Det lukkede kredsløb“, Dagens Medicin, nr. 6. september. 


\section{English Abstracts}

\section{Danish journalism students: Rather representative reporters \\ CHRISTIAN ELMELUND-PRASTEKAER, DAVID NICOLAS HOPMANN OG KLAUS LEVINSEN}

Our research based knowledge on Danish journalists is rather limited. As a step toward filling this gap this article studies Danish journalism students. The main question is who these students are, to what extent there are differences between the students from different universities, and to what extent the students can be seen as being different from the general population. Students at Roskilde University with respect to some questions appear to be a distinct group of their own. Nevertheless, the over all conclusion is that journalism students are rather re-presentative for young people with a similar socio-economic background. These conclusions are based on the largest survey analysis of Danish journalism students to date. 